-Full Paper-

\title{
Comparative Changes in the Serum Concentrations of Inhibin-B, Prolactin, Gonadotropins and Steroid Hormones at Different Reproductive States in Domestic Turkey Hens
}

\author{
Hassan A. KHALIL ${ }^{1)}$, Ahmed. M. HANAFY'), Sherif Y. SALEH ${ }^{2)}$ and Mohamed S. MEDAN ${ }^{3)}$ \\ 1) Animal Production Department, Faculty of Agriculture, ${ }^{2)}$ Biochemistry Department, Faculty of Veterinary Medicine and \\ ${ }^{3)}$ Theriogenology Department, Faculty of Veterinary Medicine, Suez Canal University, Ismailia 41522, Egypt
}

\begin{abstract}
The present study was undertaken to compare the changes in circulating levels of inhibin-B, prolactin, follicle-stimulating hormone (FSH), luteinizing hormone ( $\mathrm{LH})$, estradiol-17 $\beta$, progesterone and testosterone during the different reproductive states of turkey hens. Blood samples were collected during different reproductive states, at laying, incubating and out of lay. Inhibin-B was measured by ELISA, while other hormones were determined by Chemiluminescent Microparticle Immunoassay (CMIA). The results revealed highly significant differences among the hen's states for all serum hormone concentrations. The highest levels of inhibin-B and prolactin were observed in incubating hens, while the lowest values were observed in laying hens. In contrast, the highest levels of FSH, LH, estradiol-17 $\beta$, progesterone and testosterone were found in the laying group, while the lowest values were found in the incubating group. The progesterone level was higher in the laying group compared with the other groups. These results clearly demonstrate that negative correlation was found between both the inhibin- $B$ and prolactin levels and the gonadotropin and steroid hormone concentrations during the different reproductive states of the turkey hens. In addition, the results suggest that inhibin-B may be involved in control of FSH and LH secretion.
\end{abstract}

Key words: Turkey, Inhibin-B, Gonadotropins, Prolactin, Steroid hormones

(J. Reprod. Dev. 55: 523-528, 2009)

$\mathbf{T}$ urkey hens can rapidly shift from a laying condition to one characterized by ovarian regression, incubation behavior, hyperprolactinemia and/or out of lay [1]. Inhibin is a glycoprotein hormone consisting of two dissimilar subunits, $\alpha$ and $\beta$, that are linked by disulfide bonds and selectively suppresses follicle-stimulating hormone (FSH) secretion [2]. The existence of bioactive inhibin in testis preparations $[3,4]$ and ovarian granulosa cells $[5$, 6 ] has been reported. The effect of induction of ovarian regression and removal of ovarian follicles on plasma inhibin indicate that the ovary is the major source of inhibin in the hen [7, 8]. Prolactin secretion from the avian anterior pituitary gland is principally maintained by tonic stimulation from hypothalamic prolactinreleasing factors [9]. Prolactin secretion markedly changes during the reproductive cycle of the turkey hen. The hyperprolactinemia associated with incubation behavior (broodiness) induces ovarian regression, resulting in a substantial loss of egg production in commercial breeder flocks [10]. Administration of exogenous prolactin suppresses plasma gonadotropins necessary for egg production in domestic fowl [11]. However, there is additional evidence that suppression of gonadotropin secretion in incubating birds also involves a mechanism independent of increased prolactin secretion $[12,13]$. In turkey hens, the changes in the concentrations of inhibin-B, prolactin, gonadotropins and progesterone have been poorly documented. Therefore, in the present study, we investigated the changes in inhibin-B, prolactin, FSH, luteinizing hormone (LH), estradiol-17 $\beta$, progesterone and testosterone hor-

Accepted for publication: May 26, 2009

Published online in J-STAGE: July 14, 2009

Correspondence: MS Medan (e-mail: medan69@hotmail.com) mones during the different reproductive states.

\section{Materials and Methods}

\section{Animals and experimental design}

Domestic turkey hens (local Egyptian strain) were used in the present study. The turkeys were in the first year of production. The hens received a stimulatory photoperiod of $14 \mathrm{~h}$ of light: $10 \mathrm{~h}$ of dark throughout the experimental period and were maintained in floor pens with trap nests. They were fed commercial diets available ad libitum and had free access to water.

The hens were used at three different physiological stages (laying, incubating, and out of lay) during the experimental period. In the $1^{\text {st }}$ stage (laying), the hens laid eggs for 4 months from December to March, and 20 blood samples were collected from 5 laying hens starting on the first day of lay with a monthly interval over the next three months. In the $2^{\text {nd }}$ stage (incubating), the hens incubated eggs naturally for 4 weeks, and 25 blood samples were collected from 5 incubating hens starting on the first day of incubation with a weekly interval. In the last stage (out of lay), the hens, after natural incubation, were in rest from lay for 2 months, and 10 blood samples were collected from 5 hens during this period (one sample after 1 month and the other after 2 months from the end of natural incubation). All blood samples were taken from the wing vein in the morning.

Serum was separated and frozen at $-20 \mathrm{C}$ until assayed for hormones. Samples from the different reproductive states were assayed for inhibin-B, prolactin, FSH, LH, estradiol-17 $\beta$, progesterone and testosterone. 


\section{Hormonal assay}

Serum samples were assayed by either ELISA for inhibin-B or Chemiluminescent Microparticle Immunoassay (CMIA) for FSH, $\mathrm{LH}$, prolactin, estradiol-17 $\beta$, progesterone and testosterone using commercially available kits on an Architect system (Abbott diagnostic division, Abbott laboratories, Abbott Park, IL USA) [14].

Inhibin-B ELISA kits were purchased from Diagnostic Systems Laboratories (Webster, TX, USA). The level of inhibin-B was determined using a two-site ELISA that employs monoclonal antibodies (mAbs) raised against synthetic peptide fragments of the human $\beta$-subunit [15]. This assay has been validated for use in the chicken as described previously $[16,17]$. Recombinant human inhibin-B was used as the assay standard and the detection limit was $0.06 \mathrm{ng} / \mathrm{ml}$. The percentage of recovery was $91 \%$. The withinand between-plate coefficients of variation (CV) were 8.6 and $7.9 \%$, respectively.

The Architect FSH, LH, prolactin and estradiol-17 $\beta$ assays are two-step immunoassays using CMIA technology with flexible assay protocols, referred to as Chemiflex.

In the first step of FSH estimation, the sample and anti- $\beta$ FSHcoated paramagnetic microparticles are combined. The FSH present in the sample then binds to the anti- $\beta$ FSH-coated paramagnetic microparticles. After washing, anti- $\alpha$ FSH acridinium labeled-conjugate is added as the second step $[18,19]$. In the first step of LH estimation, the sample and anti- $\beta$ LH-coated paramagnetic microparticles are combined. The LH present in the sample then binds to the anti- $\beta$ LH-coated paramagnetic microparticles. After washing, anti- $\alpha$ LH acridinium-labeled conjugate is added as the second step $[18,19]$. In the first step of prolactin estimation, the sample and anti-prolactin-coated paramagnetic microparticles are combined. The prolactin present in the sample then binds to the anti-prolactin-coated paramagnetic microparticles. After washing, anti-prolactin acridinium-labeled conjugate is added as the second step [20]. Pre-Trigger and Trigger solution are then added to the reaction mixture; the resulting chemiluminescent reaction is measured as relative light units (RLUs). A direct relationship exists between the amount of FSH, $\mathrm{LH}$ and prolactin in a sample and the RLUs detected by the Architect optical system. The sensitivity of the assay was $0.06,0.05$ and $0.6 \mathrm{ng} / \mathrm{ml}$ and the percentage of recovery was $89.2-99.1,90-100$ and $92.4-101.1 \%$ for FSH, LH and prolactin, respectively. The intra- and interassay coefficients of variation were 2.8 and $3.3 \%, 3.4$ and $4.1 \%$ and 3.2 and $3.8 \%$, for $\mathrm{FSH}, \mathrm{LH}$ and prolactin, respectively.

In the first step of estradiol estimation, the sample, specimen diluent, assay diluent and anti-estradiol-coated paramagnetic microparticles are combined. The estradiol present in the sample then binds to the anti-estradiol-coated paramagnetic microparticles. After incubation, estradiol acridinium-labeled conjugate is added to the reaction mixture. After a second incubation and washing, PreTrigger and Trigger solution are added to the reaction mixture; the resulting chemiluminescent reaction is measured as RLUs. An inverse relationship exists between the amount of estradiol in the sample and the RLUs detected by the Architect optical system [21]. The sensitivity of the assay was $<10 \mathrm{pg} / \mathrm{ml}$. The percentage of recovery was $88.1-98.2 \%$. The intra- and interassay coefficients of variation were 5.5 and $4.8 \%$, respectively.
The Architect progesterone and testosterone assays are one-step immunoassays using CMIA technology with flexible assay protocols, referred to as Chemiflex.

The sample, antifluorescine (mouse, monoclonal) fluoresceneprogesterone complex-coated paramagnetic microparticles and anti-progesterone (sheep, monoclonal) or anti-testosterone (mouse, monoclonal) acridinium-labeled conjugate are combined to create the reaction mixture. The progesterone or testosterone present in the sample competes with the antifluorescine (mouse, monoclonal) fluorescine-progesterone complex-coated microparticles for binding with the anti-progesterone (sheep, monoclonal) or antitestosterone (mouse, monoclonal) acridinium-labeled conjugate to form antibody-antigen complexes [22, 23]. After second washing, pre-Trigger and Trigger solutions are added, and the resulting chemiluminescent reaction is measured as RLUs. An inverse relationship exists between the amount of progesterone or testosterone in the sample and the RLUs detected by the Architect optical system. The sensitivity of the assay was $0.1 \mathrm{ng} / \mathrm{ml}$ and $50 \mathrm{pg} / \mathrm{ml}$ and the percentage of recovery was $90-110 \%$ and $97-104 \%$ for progesterone and testosterone, respectively. The intra- and interassay coefficients of variation were 5.4 and $5.6 \%$ and 4 and $4.5 \%$, for progesterone and testosterone, respectively.

\section{Statistical analyses}

Values are presented as means \pm SEM. Statistical analysis was computed using the General Linear Model (GLM) procedure of SAS [24], and significant differences between means were detected using Duncan's multiple range test [25]. A probability value (P) of less than 0.05 was considered to be significant.

\section{Results}

\section{Dose response curves}

Serial dilutions of serum from adult laying turkey hens produced excellent dose-response curves (Fig. 1). The slopes of these curves were parallel with the human FSH, LH and prolactin standard curves when analyzed by one-way ANOVA $(\mathrm{P} \leq 0.05, \mathrm{n}=3)$. These results indicate that $\mathrm{FSH}, \mathrm{LH}$ and prolactin were present in the circulation of the turkey hens. Hence, the CMIA system is applicable to the turkey.

Serum concentrations of inhibin-B, prolactin, FSH and LH during different reproductive states of turkey hens

The serum concentrations of inhibin-B, prolactin, FSH and LH during the different reproductive states of turkey hens are shown in Fig. 2. The concentrations of these hormones markedly and significantly changed during the different reproductive stages. The highest inhibin-B and prolactin concentrations were obtained in the serum of incubating hens, while the lowest levels were obtained in the serum of laying hens. In contrast, the highest concentrations of FSH and LH were observed in the serum of laying hens; however, the lowest levels were observed in the serum of incubating hens.

\section{Serum concentrations of estradiol-17 $\beta$, progesterone and} testosterone during different reproductive states of turkey hens The serum concentrations of estradiol-17 $\beta$, progesterone and 


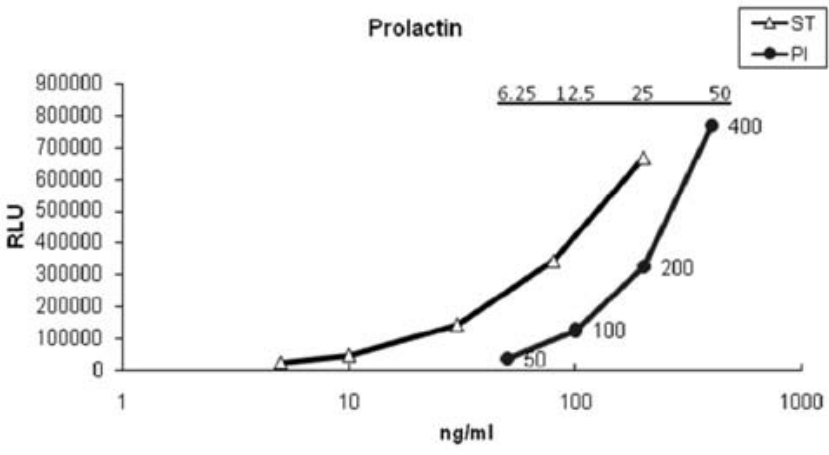

FSH
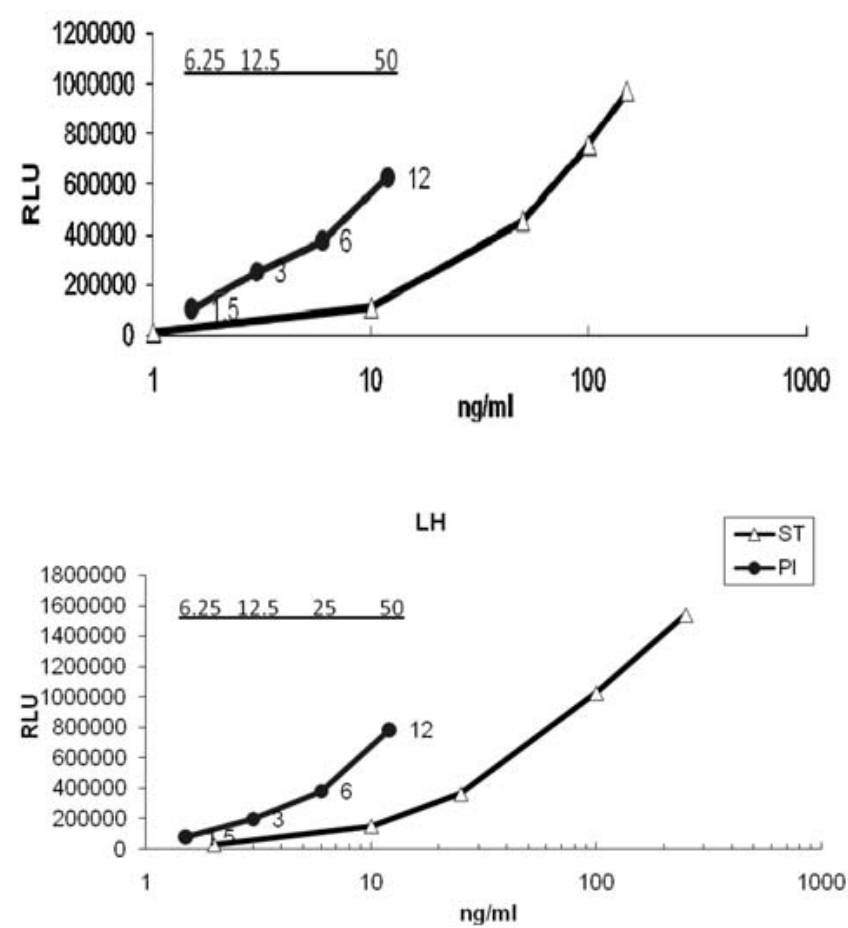

Fig. 1. Dose-response curves for the two-site CMIAs for prolactin, FSH and $\mathrm{LH}$, showing parallelism between the respective standards $(\triangle)$ and serial dilutions of pooled laying turkey serum $(\mathbf{O})$. Values are the means of triplicate determinations.

testosterone during the different reproductive states of the turkey hens are shown in Fig. 3. There were highly significant differences in the serum concentrations of these hormones during the different reproductive states. The highest levels of estradiol-17 $\beta$, progesterone and testosterone concentrations were obtained in the serum of laying hens, while the lowest levels were obtained in the serum of incubating hens.

Correlations among hormones during the different reproductive states of turkey hens

The correlation coefficients for the hormone concentrations during the different reproductive states of the turkey hens are
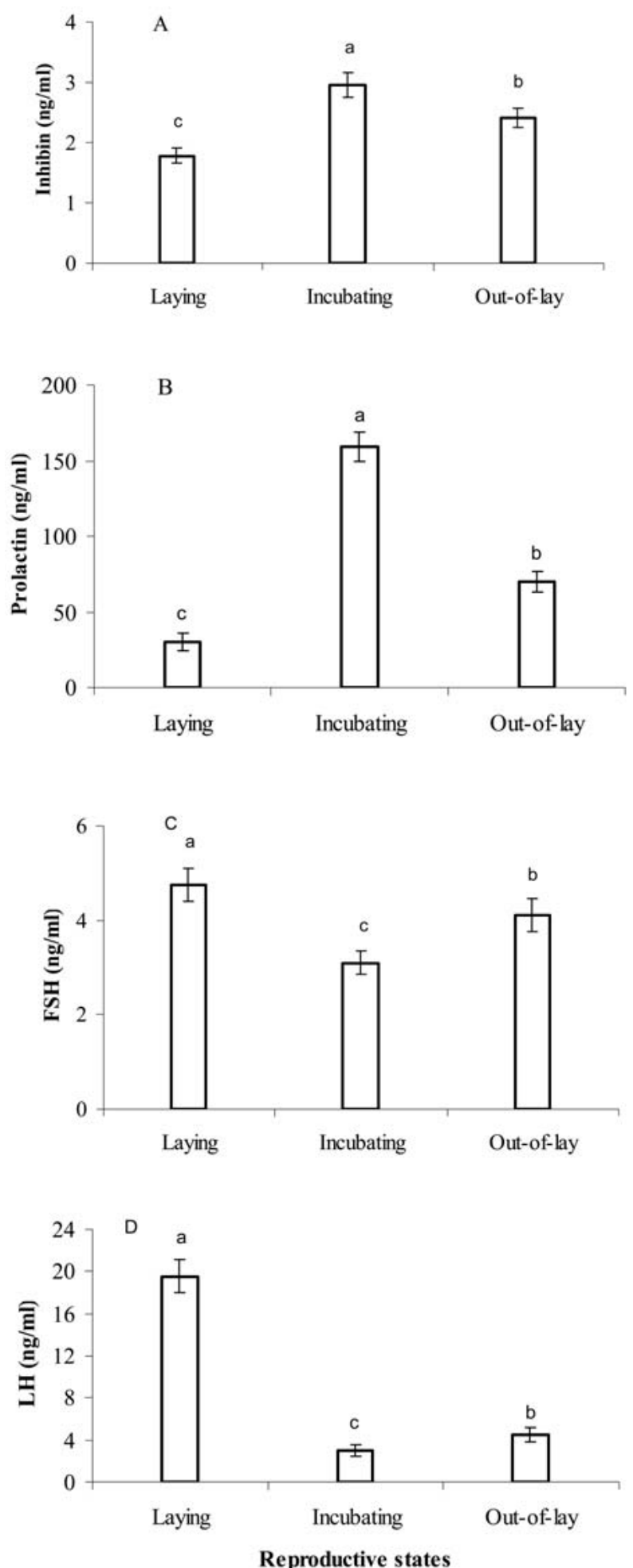

Fig. 2. Serum concentrations of inhibin-B (A), prolactin (B), FSH (C) and LH (D) during laying $(n=20)$, incubating $(n=25)$ and out of lay $(\mathrm{n}=10)$ in turkey hens. Values are means \pm SEM. Values without common characters differ significantly $(\mathrm{P} \leq 0.05)$. 

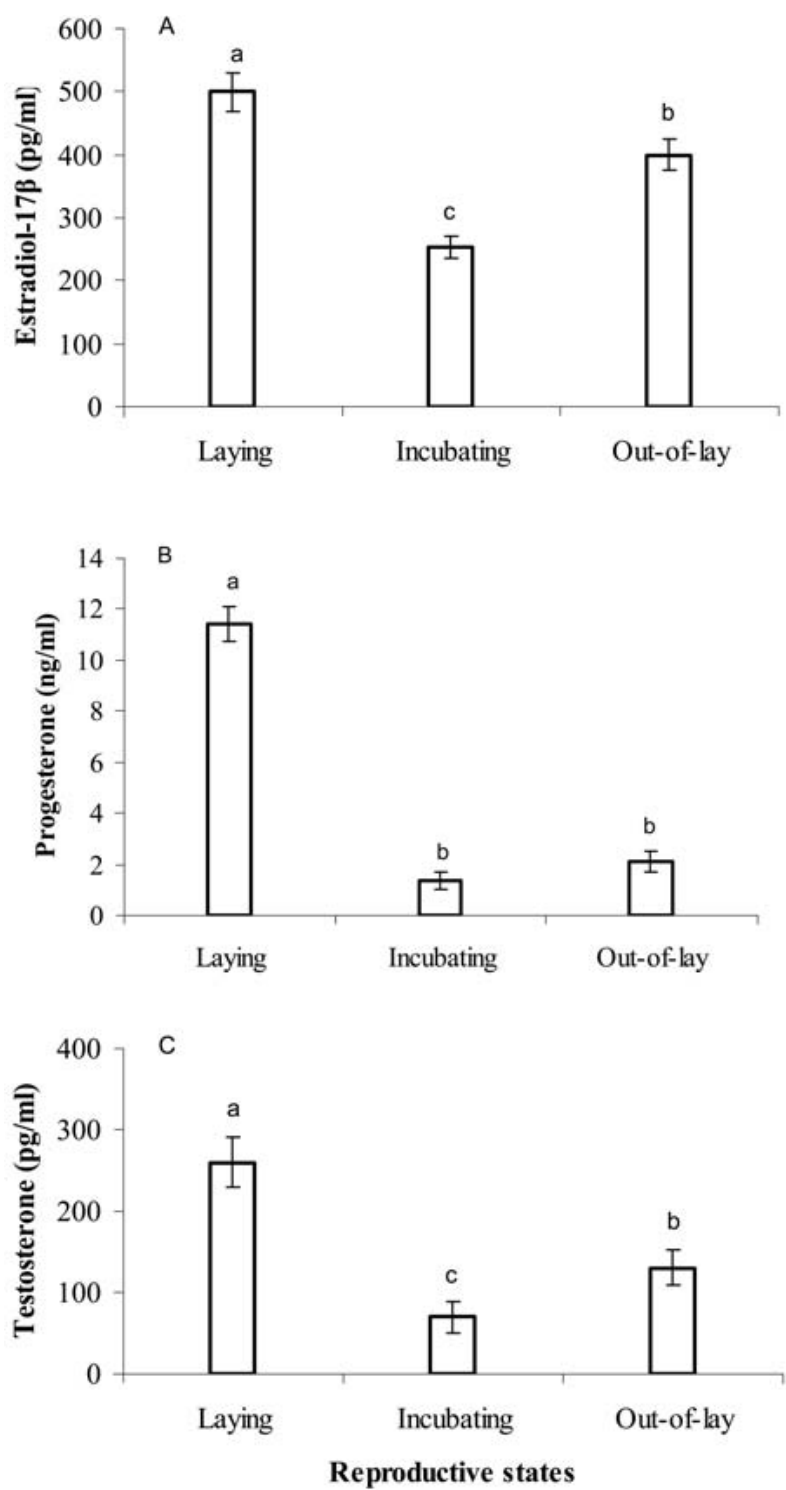

Fig. 3. Serum concentrations of estradiol-17 $\beta(\mathrm{A})$, progesterone (B) and testosterone $(C)$ during laying $(n=20)$, incubating $(n=25)$ and out of lay $(n=10)$ in turkey hens. Values are means \pm SEM. Values without common characters differ significantly $(\mathrm{P} \leq 0.05)$.

presented in Table 1 . The results revealed that there were prevalent highly significant negative correlations between both inhibin-B and prolactin and both the gonadotropin and steroid hormone concentrations. In contrast, highly significant positive correlations were found between the gonadotropin and steroid hormone concentrations during the different reproductive states of the turkey hens.

\section{Discussion}

In the present study, we investigated the changes in circulating levels of inhibin-B, prolactin, FSH, LH, estradiol-17 $\beta$, progesterone and testosterone during the different reproductive states of turkey hens. This study clearly demonstrates that inhibin-B, prolactin, gonadotropins and steroid hormones were secreted throughout laying, incubating and out of lay, but the concentrations of these hormones differed significantly $(\mathrm{P} \leq 0.0001)$ according to reproductive states of the turkey hens. Our findings demonstrated that the laying period was characterized by higher serum concentrations of FSH, LH, estradiol-17 $\beta$, progesterone and testosterone and lower concentrations of inhibin-B and prolactin than the other reproductive states. In contrast, the incubating period was characterized by higher serum concentrations of inhibin-B and prolactin and lower concentrations of gonadotropins and steroid hormones than the other reproductive states. In the chicken ovary, the main source of progesterone is cells of the granulosa layer, whereas the main source of estradiol is cells of the theca layer [26, 27]. The steroidogenic activity of a particular layer changes during the different physiological states of the ovary [28-31]. During maturation of yellow preovulatory follicles, the production of estrogens by the theca layer gradually decreases while synthesis of progesterone by the granulosa layer dramatically increases. Hence, the largest F1 follicle during the final hours before ovulation produces mainly progesterone [27, 32], which is responsible for triggering the preovulatory LH surge and ovulation [33].

Inhibin, a dimeric glycoprotein hormone, is primarily produced by the follicular granulosa cells of female mammals [34]. In the chicken, the granulosa cells of the largest follicles of the laying hen are the primary source of inhibin [35]. Chen and Johnson [36] reported that small preovulatory follicles produce the primary ovarian inhibin, which plays an autocrine or paracrine role in hen preovulatory follicles. In a subsequent report, Inhibin-B mRNA was also shown to be expressed in the hierarchical follicles, with the highest expression in the granulosa layers of small yellow follicles and undetectable in the largest follicles [37, 38]. Previous results indicate that intact inhibin-B is secreted in the greatest quantity from the small follicles of the hen, which suggests that these follicles could be a primary source of inhibin-B [39, 40]. Furthermore, the plasma inhibin-B levels are highest early in the cycle of the rat in the presence of small growing follicles [41]. Consistent with the previous results, higher serum levels of inhibin-B during the incubation period cannot be excluded. Our results showed that the levels of serum inhibin-B rose and serum FSH fell during the incubation period of the turkey hens. These data imply that small follicles are an important source of inhibin-B and, at least, may suggest a dominant endocrine role for inhibin-B in the turkey hen [8].

A negative correlation was found between inhibin-B and both gonadotropins and steroid hormones. The results demonstrated that the highest level of serum inhibin-B coincided with the lowest levels of gonadotropins and steroids hormones. These results are in agreement with those of previous studies. Culler and Negro-Vilar [42] reported a negative relationship between FSH and inhibin in the postnatal rat. Also, the relationship between pituitary gonadotropins and gonadal inhibin has been characterized from hatching to maturity in chickens [43, 44]. Both studies found a negative relationship between inhibin and FSH in female chickens that appeared to become functional at sexual maturity. Removal of large follicles leads to a rise in plasma the FSH level, indicating a possible endo- 
Table 1. Correlation coefficients between the hormone levels during different reproductive states

\begin{tabular}{llccccc}
\hline Hormone & Prolactin & FSH & LH & Estradiol-17 $\beta$ & Progesterone & Testosterone \\
\hline Inhibin-B & $0.945^{* * *}$ & $-0.933^{* * *}$ & $-0.944^{* * *}$ & $-0.924^{* * *}$ & $-0.923^{* * *}$ & $-0.965^{* * *}$ \\
Prolactin & 1.000 & $-0.932^{* * *}$ & $-0.898^{* * *}$ & $-0.982^{* * *}$ & $-0.895^{* * *}$ & $-0.961^{* * *}$ \\
FSH & & 1.000 & $0.873^{* * *}$ & $0.908^{* * *}$ & $0.881^{* * *}$ & $0.906^{* * *}$ \\
LH & & 1.000 & $0.827^{* * *}$ & $0.995^{* * *}$ & $0.979^{* * *}$ \\
Estradiol-17 $\beta$ & & & 1.000 & $0.817^{* * *}$ & $0.921^{* * *}$ \\
Progesterone & & & & 1.000 & $0.971^{* * *}$ \\
Testosterone & & & & & 1.000 \\
\hline
\end{tabular}

$* * * \mathrm{P} \leq 0.0001$.

crine role for inhibin in FSH regulation in the chicken [8]. Inhibin plays an important role in control of FSH secretion during the ovulatory cycle in the duck [45]. It has been shown to block binding of FSH to its receptor on ovarian granulosa cells [46]. Recently, Huang et al. [47] reported a negative correlation between inhibin and LH during the reproductive cycle in Magang geese.

It is well known that prolactin plays the most important role in the timing and duration of incubation behaviour in broody birds [48-51]. In the present study, prolactin secretion markedly changed during the reproductive cycles of the turkey hens. The hyperprolactinemia associated with incubation behavior (broodiness) induces ovarian regression [10, 47, 52], resulting in a substantial loss of egg production and inhibition of reproductive activities in many avian species. Prolactin secretion in birds is under the stimulatory control of vasoactive intestinal peptide (VIP). Active immunization with VIP results in a substantial reduction in the plasma prolactin concentration and an increase in flock egg production due to the elimination of incubation behavior [53].

The results show a highly significant negative correlation between prolactin and both gonadotropins and steroid hormones, with the highest level of serum prolactin coinciding with the lowest levels of gonadotropins and steroid hormones. These results are in agreement with other findings reported previously [42, 50, 54, 55].

Prolactin decreases reproductive activity by acting on the hypothalamus and inhibiting gonadotropin-releasing hormone release, acts on the pituitary to reduce LH- $\beta$ subunit mRNA expression and LH release [56] and acts directly on the ovary, reducing steroidogenic enzyme mRNA expression, thus inhibiting steroid hormone production [57]. The prolonged elevation of the levels of prolactin during the incubation period has an antisteroidogenic effect on the ovary [58-61] in part via inhibition of steroidogenic enzyme gene expression [57].

In a short communication, prolactin was shown to have an inhibitory effect on the stimulatory action of FSH and LH on theca cell function in vitro [62]. Moreover, expression of prolactin receptor mRNA is evidence that the chicken ovary is a target tissue for prolactin [54, 63, 64]. Finally, prolactin has been shown to have an inhibitory effect on gonadotropin-stimulated estradiol secretion in vitro by white follicles in laying and out-of-lay Gifujidori hens [61].

In summary, this study provided a detailed endocrine profile during different physiological situations in turkey species and demonstrated that reproductive hormones are involved in regulation of the reproductive activities of turkey hens. The rise in inhibin-B is correlated with the non-laying period of female turkey hens. Furthermore, inhibin-B may contribute to regulation of FSH and $\mathrm{LH}$ secretion during the reproductive cycles of turkey hens. However, further studies are needed to investigate the rise of inhibin-B and its role during incubation behavior.

\section{References}

1. Ramachandran R, John AP, Wayne JK. Changes in pituitary somatotroph and lactotroph distribution in laying and incubating turkey hens. Gen Comp Endocrinol 1996; 104: $67-75$

2. Vale W, Rivier J, Hsueh A. Chemical and biological characterization of the inhibin family of protein hormones. Recent Prog Horm Res 1988; 44: 1-34.

3. Bandivdekar AH, Vijiyalakahmi S, Moodbidri SB, Sheth AR. Low-molecularweight inhibin from sheep, human, rat and chicken testes. J Andrology 1982; 3: 140-143.

4. Sedqyar M, Wing Q, Watanabe G, Kandeil M, Takahashi S, Suzuki A, Taneda S, Taya A. Secretion of inhibin in male Japanese quail (Coturnix japonica) from one week of age to sexual maturity. J Reprod Dev 2008; 54: 100-106.

5. Akashiba H, Taya K, Sasamoto S, Goto H, Kamiyoshi M, Tanaka K. Secretion of inhibin by chicken granulosa cells in vitro. Poult Sci 1988; 67: 1625-1631.

6. Sedqyar M, Wing Q, Watanabe G, Kandeil M, Takahashi S, Suzuki A, Taneda S, Taya A. Secretion of inhibin in female Japanese quail (Coturnix japonica) from hatch to sexual maturity. J Reprod Dev 2008; 54: 52-57.

7. Vanmontfort D, Berghman LR, Rombauta L, Verhoeven G, Decuypere E. Changes in immunoreactive inhibin, follicle-stimulating hormone, lutenizing hormone and progesterone in plasma after short-term food deprivation and during the ovulatory cycle of the hen. Gen Comp Endocrinol 1994; 95: 117-124.

8. Johnson PA, Brooks C, Wang SY, Chen CC. Plasma concentrations of immunoreactive inhibin and gonadotropins following removal of ovarian follicles in the domestic hen. Biol Reprod 1993; 49: 1026-1031.

9. Bern HA, Nicoll CS. The comparative endocrinology of prolactin. Recent Prog Horm Res 1968; 24: 681-720.

10. E1 Halawani ME, Fehrer S, Hargis BM, Porter TE. Incubation behavior in the domestic turkey. Physiological Correlates CRC Crit Rev Poult Biol 1988; 1: 285-314.

11. Lea RW, Richard-Yris MA, Sharp PJ. The effect of ovariectomy on concentrations of plasma prolactin and LH and parental behavior in the domestic fowl. Gen Comp Endocrinol 1996; 101: 115-121.

12. Sharp PJ, Macnamee MC, Sterling RJ, Lea RW, Pedersen HC. Relationships between prolactin, LH and broody behaviour in bantam hens. J Endocrinol 1988; 118: 279-286.

13. Sharp PJ, Sterling RJ, Talbot RT, Huskisson NS. The role of hypothalamic vasoactive intestinal polypeptide in the maintenance of prolactin secretion in incubating bantam hens: Observations using passive immunization, radioimmunoassay and immunohistochemistry. J Endocrinol 1989; 122: 5-13.

14. AIDD Longford. Abbott laboratories, Abbott Park, IL USA, 2006

15. Groome NP, Illingworth PJ, O'Brien M, Pai R, Rodger FE, Mather, JP, McNeilly AS Measurement of dimeric inhibin B throughout the menstrual cycle. J Clin Endocrinol Met 1996; 81: 1401-1405.

16. Lovell TM, Knight PG, Groome NP, Gladwell RT. Measurement of dimeric inhibins and effects of active immunization against inhibin $\alpha$-subunit on plasma hormones and testis morphology in the developing cockerel. Biol Reprod 2000; 63: 213-221.

17. Lovell TM, Knight PG, Groome NP, Gladwell RT. Changes in plasma inhibin A levels during sexual maturation in the female chicken and the effects of active immuniza- 
tion against inhibin $\alpha$-subunit on reproductive hormone profiles and ovarian function. Biol Reprod 2001; 64: 188-196.

18. Pierce JG, Parsons TF. Glycoprotein hormones: structure and function. Ann Rev Biochem 1981; 50: 465-495.

19. Beastall GH. Assay for FSH and LH: guidelines for the provision of a clinical biochemistery service. Ann Clin Biochem 1987; 24: 246-262.

20. Friesen H, Guyda H, Hwang P, Tyson JE, Barbeau A. Functional evaluation of prolactin secretion: A guide to therapy. J Clin Invest 1972; 51: 706-709.

21. Whitley RJ, Meikle AW, Watts NB. Tietz Textbook of Clinical Chemistery, $2^{\text {nd }}$ ed., Philadelphia: W.B. Saunders Company. 1994: 1843-1886.

22. Abraham GE, Odell WD, Swerdloff RS, Hopper K. Simultaneous radioimmunoassay of plasma FSH, LH, progesterone, and estradiol-17 $\beta$ during menstrual cycle. J Clin Endocr 1972; 34: 312-318.

23. Burtis CA, Ashwood ER. Teitz Textbook of Clinical Chemistry" $2^{\text {nd }}$ ed., Philadelphia: W.B. Saunders Company. 1994: 1850-1851

24. SAS Institute. SAS Statistical Guide for Personal Computer, 1998; Cary, NC SAS Institute Inc.

25. Duncan DB. Multiple range and multiple F-test. Biometrics 1955; 11: 1-42.

26. Bahr JM, Wang SC, Huang MY, Calvo FO. Steroid concentrations in isolated theca and granulosa layers of preovulatory follicles during the ovulatory cycle of the domestic hen. Biol Reprod 1983; 29: 326-334.

27. Etches RJ, Dukec E. Progesterone, androstendione and oestradiol content of theca and granulosa tissue of the four largest ovarian follicles during the ovulatory cycle of the hen (Gallus domesticus). J Endocrol 1984; 103: 71-76.

28. Kacinska M, Rzysa J. Activity of hydroxysteroid dehydrogenase in the ovarian follicles of the domestic hen. $21^{\text {st }}$ Int Conf Poult Physiol Praga Abstr 1988; 19-20.

29. Nitta H, Osawa Y, Bahr JM. Immunolocalization of steroidogenic cells in small follicles of the chicken ovary: anatomical arrangement and localization of steroidogenic cells change during follicular development. Domest Anim Endocrinol 1991; 8: 587-594.

30. Rodriguez-Maldonado E, Valazquez PN, Juarez-Oropeza MA, Pedernera E. Steroid metabolism in the theca externa cells from preovulatory follicles of domestic hen (Gallus domesticus). Gen Comp Endocrinol 1996; 101: 173-179.

31. Gomez Y, Velazquez PN, Juarez-Orapeza MA, Pedernera E. Steroid metabolism in granulosa and theca interna cells from preovulatory follicles of domestic hen (Gallus domesticus). Anim Reprod Sci 1998; 52: 81-91.

32. Marrone BL, Hertelendy F. Steroid metabolism by avian ovarian cells during follicular maturation. Biol Reprod 1983; 29: 953-962.

33. Johnson PA, Johnson AL, Van Tienhoven A. Evidence for a positive feedback interaction between progesterone and luteinizing hormone in the induction of ovulation in the hen Gallus domesticus. Gen Comp Endocrinol 1985; 58: 478-485.

34. Erickson GF, Hsueh AJ. Secretion of inhibin by rat granulosa cells in vitro. Endocrinol 1978; 103: 1960-1963.

35. Vanmontfort D, Rombauts L, Decuypere E, Verhoeven G. Source of immunoreactive inhibin in the chicken ovary. Biol Reprod 1992; 47: 977-983.

36. Chen CC, Johnson PA. Expression of inhibin $\alpha$ and inhibin/activin $\beta$ A-subunits in the granulosa layer of the large preovulatory follicles of the hen. Biol Reprod 1996; 55: 450-454.

37. Davis AJ, Johnson PA. Expression pattern of messenger ribonucleic acid for follistatin and the inhibin/activin subunits during follicular and testicular development in (Gallus domesticus). Biol Reprod 1998; 59: 271-277.

38. Lovell TM, Gladwell RT, Groome NP, Knight PG. Differential effects of activin A on basal and gonadotrophin induced secretion of inhibin A and progesterone by granulosa cells from preovulatory (F1-F3) chicken follicles. Reprod 2002; 124: 649-657.

39. Hecht DJ, Davis AJ, Brooks CF, Johnson PA. Molecular cloning and expression analysis of the complementary deoxyribonucleic acid for chicken inhibin/activin $\beta \mathrm{B}$ subunit. Biol Reprod 2000; 62: 1128-1134.

40. Johnson PA, Brooks CF, Davis AJ. Pattern of secretion of immunoreactive inhibin/ activin subunits by avian granulosa cells. Gen Comp Endocrinol 2005; 141: 233-239.

41. Woodruff TK, Besecke LM, Groome N, Draper LB, Schwartz NB, Weiss J. Inhibin A and inhibin $\mathrm{B}$ are inversely correlated to follicle-stimulating hormone, yet are discordant during the follicular phase of the rat estrous cycle, and inhibin A is expressed in a sexually dimorphic manner. Endocrinol 1996; 137: 5463-5467.

42. Culler MD, Negro-Vilar A. Passive immunoneutralization of endogenous inhibin: sex-related differences in the role of inhibin during development. Mol Cell Endocrinol 1988; 58: 263-273.

43. Johnson PA, Brooks C. Developmental profile of plasma inhibin and gonadotropins from hatch to sexual maturity in male and female chickens. Gen Comp Endocrinol 1996; 102: 56-60.

44. Vanmontfort D, Berghman LR, Rombauts L, Verhoeven G, Decuypere E. Developmental changes in immunoreactive inhibin and FSH in plasma of chickens from hatch to sexual maturity. Br Poult Sci 1995; 36: 779-790.

45. Yang P, Medan MS, Arai KY, Watanabe G, Taya K. Plasma concentration of immunoreactive (ir)-inhibin, gonadotropins and steroid hormones during the ovulatory cycle of the duck. J Reprod Dev 2005; 51: 353-358.

46. Schneyer AL, Sluss PM, Whitcomb RW, Martin KA, Sprengel R, Crowley WF. Precursors of $\alpha$-inhibin modulate follicle-stimulating hormone receptor binding and biological activity. Endocrinol 1991; 129: 1987-1999.

47. Huang YM, Shi ZD, Liu Z, Liu Y, Li XW. Endocrine regulations of reproductive seasonality, follicular development and incubation in Magang geese. Anim Rep Sci 2008; 104: 344-358.

48. E1 Halawani ME, Silsby JL, Behnke EJ, Fehrer SC. Hormonal induction of incubation in ovariectomized female turkeys (Meleagris gallopavo). Biol Reprod 1986; 35: 59-67.

49. Youngren OM, EL Halawani ME, Silsby JL, Phillips RE. Intracranial prolactin perfusion induces incubation behavior in turkey hens. Biol Reprod 1991; 44: 425-443.

50. E1 Halawani ME, Rozenboim I. The ontogeny and control of incubation behavior in turkeys. Poult Sci 1993; 72: 906-911.

51. March JB, Sharp PJ, Wilson PW, Sang HM. Effect of active immunization against recombinant-derived chicken prolactin fusion protein on the onset of broodiness and photoinduced egg laying in bantam hens. J Reprod Fertil 1994; 101: 227-233.

52. Shi ZD, Huang YM, Liu Z, Liu Y, Li XW. Proudman JA, Yu RC. Seasonal and photoperiodic regulation of secretion of hormones associated with reproduction in Magang goose ganders. Dom Anim Endocrinol 2007; 32: 190-200.

53. E1 Halawani ME, Silsby JL, Rozenboim I, Pitts GR. Increased egg production by active immunization against vasoactive intestinal peptide in the turkey (Meleagris gallopavo). Biol Reprod 1995; 52: 179-183.

54. Anna H, Helena P, Janusz R. Effect of prolactin on estradiol and progesterone secretion by isolated chicken ovarian follicles. Folia Biologica 2004; 52: 3-4.

55. Rozenboim I, Mobarky N, Heiblum R, Chaiseha Y, Kang SW, Biran I, Rosenstrauch A, Sklan D, El Halawani ME. The role of prolactin in reproductive failure associated with heat stress in the domestic turkey. Boil Reprod 2004; 71: 1208-1213.

56. You S, Silsby JL, Farris J, Foster DN, El Halawani ME. Tissue-specific alternative splicing of turkey, preprovasoactive intestinal peptide messenger ribonucleic acid, its regulation, and correlation with prolactin secretion. Endocrinol 1995; 136: 2602-2610.

57. Tabibzadeh C, Rozenboim I, Silsby JL, Pitts GR, Foster DN, E1 Halawani ME. Modulation of ovarian cytochrome P450 17-hydroxylase and cytochrome aromatase messenger ribonucleic acid by prolactin in the domestic turkey. Biol Reprod 1995; 52: 600608

58. Burke WH, Dennison PT. Prolactin and luteinizing hormone levels in female turkeys (Meleagris gallopavo) during a photoinduced reproductive cycle and broodiness. Gen Comp Endocrinol 1980; 41: 92-100.

59. Bedrak E, Harvey S, Chadwick A. Concentration of pituitary, gonadal and adrenal hormones in serum of laying and broody white rock hens (Gallus domesticus). J Endocrinol 1981; 89: 197-204.

60. Zadworny D, Etches RJ. The effect of PMSG on plasma prolactin, LH, estradiol and ovarian growth in incubating and out-of-lay turkey hens. Poult Sci 1988; 67: 319-326.

61. Zadworny D, Shimada K, Ishida H, Sato K. Gonadotropin-stimulated estradiol production in small ovarian follicles of the hen is suppressed by physiological concentrations of prolactin in vitro. Gen Comp Endocrinol 1989; 74: 468-473.

62. Li YH, Yang CR. Effect of prolactin on the steroidogenesis and proliferation of cultured theca cells from domestic hens. Poult Avian Biol Rev 1995; 6: 295. Abstract.

63. Ohkubo T, Tanaka M, Nakashima K, Talbot RT, Sharp PJ. Prolactin receptor gene expression in the brain and peripheral tissues in broody and nonbroody breeds of domestic hen. Gen Comp Endocrinol 1998; 109: 60-68.

64. Reddy IJ, David CG, Sarma PV, Singh K. The possible role of prolactin in laying performance and steroid hormone secretion in domestic hen (Gallus domesticus). Gen Comp Endocrinol 2002; 127: 249-255. 